\title{
Review
}

\section{Benefits of FES gait in a spinal cord injured population}

\author{
EJ Nightingale*, J Raymond, JW Middleton, J Crosbie and GM Davis \\ Faculty of Health Sciences, University of Sydney, Sydney, New South Wales, Australia
}

\begin{abstract}
Study design: Review.
Objectives: This review article investigated the objective evidence of benefits derived from functional electrical stimulation (FES)-assisted gait for people with spinal cord injury (SCI). Both FES and gait have been proposed to promote not only augmented health and fitness, but specific ambulatory outcomes for individuals with neurological disabilities. However, due to small sample sizes and the lack of functionality of the intervention, it has not been widely used in clinical practice. This review assessed whether there is sufficient evidence to encourage a more widespread deployment of FES gait within the rehabilitation community.

Methods: Hand searches and online data collection were performed in Medline and Science Direct. Specific search terms used included SCI/paralysis/paraplegia and tetraplegia with electrical stimulation/FES, gait and walking.

Results: The searches generated 532 papers. Of these papers, 496 were excluded and 36 papers were included in the review. Many reported benefits were not carefully investigated, and small sample sizes or different methodologies resulted in insufficient evidence to draw definitive conclusions.

Conclusions: FES gait can enhance gait, muscle strength and cardiorespiratory fitness for people with SCI. However, these benefits are dependent on the nature of the injury and further research is required to generalize these results to the widespread population of SCI individuals. Proof of the functionality and further evidence of the benefits of FES gait will assist in FES gait gaining clinical acceptance.

Spinal Cord (2007) 45, 646-657; doi:10.1038/sj.sc.3102101; published online 24 July 2007
\end{abstract}

Keywords: functional electrical stimulation; spinal cord injury; gait

\section{Introduction}

Since the 1980s, functional electrical stimulation (FES) has been used by people with spinal cord injury (SCI) to generate purposeful contractions of paralyzed muscles, thereby enabling functional activities such as cycling, standing and stepping. In addition to increasing functional upright mobility, chronic use of FES may offer therapeutic benefits such as decreasing muscle spasm, increasing blood flow to stimulated areas, increasing muscle strength in paralyzed muscles and improving cardiorespiratory fitness. $^{1-5}$

In several surveys assessing the utility of FES to promote functional outcomes, individuals with SCI have often identified standing and walking as very high priorities within rehabilitation, ${ }^{6}$ particularly for those with incomplete impairments or lower level complete lesions. ${ }^{7}$ Loss of upright mobility following SCI not only impacts on function and independence, but may

*Correspondence: EJ Nightingale, Physiotherapy, Faculty of Health Sciences, University of Sydney, PO Box 170, Lidcombe 1680, Sydney, New South Wales, Australia adversely affect psychosocial outlook and quality of life. ${ }^{1-3}$ FES gait has been deployed within research settings to restore basic stepping, but its use has not moved into mainstream clinical practice due to a perceived lack of functional community ambulation. There may, however, be some secondary benefits attributable to FES gait, which might encourage and support a greater clinical application than currently occurs.

Benefits of FES gait training can be categorized into three main domains: clinical outcomes, fitness benefits and functional gains. Although previous reviews have investigated these outcomes for interventions such as FES cycling (Raymond and Crameri, ${ }^{5}$ and Jacobs and $\mathrm{Nash}^{8}$ ), no systematic evaluation has been conducted on the efficacy of FES gait. This information is important, because it can demonstrate that the outcomes achieved with FES gait training extend beyond the actual performance of gait itself, and therefore such training may be seen as having broader advantages by both the FES user and the clinician. One reason why uncertainty 
exists in the rehabilitation-provider community is that FES gait studies have typically included small sample sizes and quite heterogeneous populations which is a common problem across the SCI research area. ${ }^{9}$ This has led to results from many research studies being statistically under-powered. Thus, it has been difficult to make unambiguous conclusions from individual studies for what (if any) secondary benefits may exist. On the other hand, systematic collation of results from multiple studies might permit significant conclusions to be drawn. Therefore, the purpose of this review was to synthesize evidence of clinical, fitness-related and functional benefits after FES gait training in people with SCI. A secondary purpose was to compare the functionality of FES gait to conventional orthotic gait.

\section{Methods}

\section{Search strategy}

Relevant articles were identified by searching Medline and Science Direct from the earliest record until December 2006. In addition, relevant articles were also identified through citations in indexed journal publications and published conference proceedings. Search terms included those for 'spinal cord injury', 'paralysis', 'paraplegia' and 'tetraplegia' with 'electrical stimulation', 'functional electrical stimulation', 'gait' and 'walking'. Secondary search terms included 'treatment studies', 'follow up', 'clinical' and 'controlled trials' to narrow the searches to clinical trials rather than studies investigating methods of electrical stimulation to acquire gait. Only English references were included.

\section{Eligibility criteria}

The abstracts of all studies identified by the search strategy were screened by the first author against the following inclusion criteria: (i) participants were humans with SCI; (ii) the study involved a period of FES gait training; (iii) one or more objective/quantifiable measures in the clinical, fitness-related or functional domains; and (iv) outcomes were included at baseline and follow up. Clinical outcomes that were examined included reduced spasticity, decreased frequency of pressure sores, improvements in bone density, muscle strength and length, joint changes and psychological well-being. Fitness-related outcomes were assessed through cardiorespiratory measures. Functionality was reflected by gait parameters, walking efficiency, as well as performance of functional tasks (for example, activities of daily living). Studies were excluded if they were reported as abstract only (except in cases where all information could be extracted) or used subjective assessment methods, such as manual muscle testing.

\section{Data extraction and analysis}

The baseline and follow-up data for all outcome measures relating to the three domains of potential benefits after FES gait training were extracted. Details regarding the patient population used in the study, the length of the training period and the method used to obtain the outcome measure(s) were also recorded. A meta-analysis was not undertaken due to substantial differences in the training methods employed and multiple methodologies used to evaluate the same outcome.

To compare the functionality of FES gait to orthosissupported gait, an analogous data extraction paradigm was employed, with the underlying patient population, duration of training and assessment methods collected. Differences in the outcome measures are highlighted.

\section{Results}

Included studies

The electronic and manual searches generated 532 papers. Of these papers, 496 were excluded; comprising of 30 animal studies, 67 lacking a cohort of SCI, 159 were not treatment studies, 51 were not gait studies, 172 did not use FES and 17 did not have baseline and follow-up measures (Figure 1). Thirty-six papers were included in the review.

Outcomes measured were muscle strength, spasm and bone mineral density, joint health, cardiorespiratory fitness and energy expenditure during gait, gait parameters (for example, velocity, step length, joint kinematics and temporal features) and function on activities of daily living. The incidence of pressure sores, bladder and bowel function, and muscle length were not evaluated by any studies. The characteristics of the included studies are presented in Tables 1-7. In the tables, some studies have been grouped together due to an apparent use of the same sample or duplication of some outcomes among studies. Sample overlap was also noted in some reports where the Parastep system was investigated, but since each paper reported different outcomes these have been recorded as discrete studies.

Several studies were also found that compared single sessions of orthotic gait versus FES gait, typically after an FES gait intervention. These are presented in Table 8 allowing comparison of orthotic and FES gait.

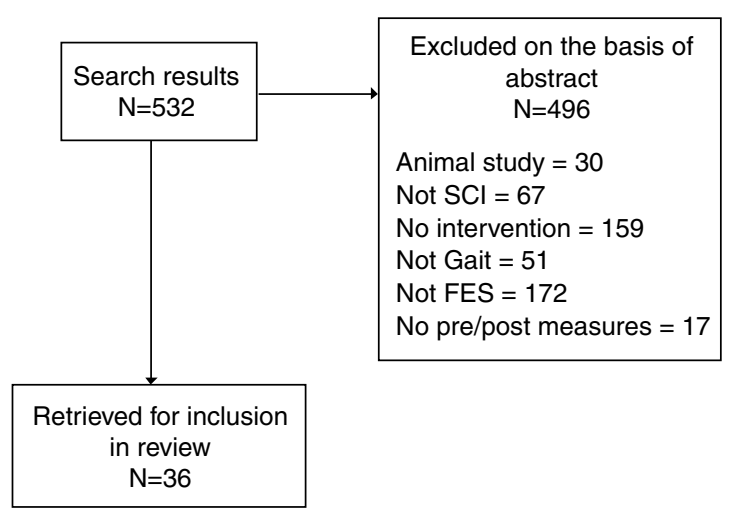

Figure 1 Flow chart of searches, inclusions and exclusions 
Table 1 Summary of investigations into spasticity

\begin{tabular}{lll}
\hline Reference & Method & Spasticity \\
\hline Spadone et al $(2003)^{10}$ & $\begin{array}{l}\text { Single case study of T4/5 complete SCI } \\
50 \text { sessions Hybrid Orthotic and 50 of Parastep } \\
\text { Measured at the completion of all gait training }\end{array}$ & Pendulum test: low initial levels with no change \\
& $\begin{array}{l}\text { 6 incomplete SCI } \\
\text { 6 mo. strengthening, 3 mo. gait training } \\
\text { Mranat et al }(1992)^{11}\end{array}$ & Pendulum test: sig. dec. except for one patient \\
Granat et al $(1993)^{12}$ & & \\
Mirbagheri et al $(2002)^{13}$ & $\begin{array}{l}\text { 9 incomplete SCI } \\
\text { Home program of FES walking in ADLs } \\
4 \text { of 9 completed 16-18 mo. program }\end{array}$ & $\begin{array}{l}\text { Ankle perturbations: sig. dec. in intrinsic and } \\
\text { reflex stiffness }\end{array}$ \\
& &
\end{tabular}

Abbreviations: ADL, activities of daily living; dec., decrease; FES, functional electrical stimulation; mo., month(s); SCI, spinal cord injury; sig., significant (a $P$-level of 0.05 or less achieved)

Table 2 Summary of investigations into BMD

\begin{tabular}{lll}
\hline Reference & Method & Bone density \\
\hline Spadone et al (2003) & Single case study of T4/5 complete SCI & Femoral BMD: no change \\
& $\begin{array}{l}50 \text { sessions Hybrid Orthotic and 50 of Parastep } \\
\text { Measured at the completion of all gait training }\end{array}$ & \\
Needham-Shropshire et al (1997) $)^{14}$ & $\begin{array}{ll}16 \text { complete SCI } \\
\text { Parastep program plus 8-wk home use }\end{array}$ & $\begin{array}{l}\text { Femoral head, neck and Ward's } \\
\text { Triangle BMD: no change }\end{array}$ \\
\hline
\end{tabular}

Abbreviations: BMD, bone mineral density; SCI, spinal cord injury; wk, week(s)

\section{Study quality}

No randomized controlled trials (RCTs) were identified in this field of inquiry. Furthermore, most studies lack control data.

\section{Outcomes following FES gait training}

Clinical outcomes Muscle spasm: Spasticity was considered by three studies (Table 1) using objective criteria (pendulum test or ankle perturbations). Two of the three studies $^{11,13}$ reported a decrease in spasticity in participants with incomplete SCI whereas the other study, a single case study of a participant with complete SCI, reported no change, although the authors indicated that their participant's initial spasticity was low. ${ }^{10}$

Bone mineral density: Bone mineral density has been considered in two studies (Table 2). Both studies failed to find any change in bone mineral density following 3-4 months of FES gait training.

Muscle strength: Eight studies evaluated lower limb muscle strength following FES gait training by measuring quadriceps force or torque or by making inferences based on changes in thigh girth or muscle mass (Table 3 ). Seven of these studies used participants with complete SCI, whereas the remaining study included participants with incomplete injuries. Increases in muscle strength and/or muscle girth were observed in all studies.
Other: Data from an American hospital ${ }^{42,43}$ evaluating knee and ankle joint changes after FES gait used magnetic resonance imaging and synovial biopsies. These data demonstrated improvements in pre-existing pathologies. Effusions and cartilage matrix glycoproteins in synovial fluid either remained stable or improved confirming no deleterious effects occurring from FES gait and possible benefits to joint health.

Only one study ${ }^{44}$ considered the psychological effects of FES gait using the Tennessee Self Concept Scale and Beck Depression Inventory. This report demonstrated improvements on the physical self-concept sub-scale of the Tennessee Self Concept Scale, and decreased depression on the Beck Depression Inventory.

Cardiorespiratory fitness outcomes Table 4 summarizes two investigations that objectively measured aerobic fitness. Jacobs et al ${ }^{19}$ employed a graded peak arm crank ergometry after 11 weeks of FES gait training, and the authors noted increased arm work capacity, $\mathrm{VO}_{2 \text { peak }}$, $\mathrm{HR}_{\text {peak }}$ and an improved resistance to fatigue. In contrast, Brissot et $a l^{18}$ in a single case observed no difference in $\mathrm{VO}_{2 \text { peak }}$ or $\mathrm{HR}_{\text {peak }}$ during a maximal effort FES walking test. Dissimilar methodologies, small sample sizes and disparate lengths of intervention/follow up make these studies very difficult to compare. 
Table 3 Summary of investigations into muscle strength

\begin{tabular}{|c|c|c|}
\hline Reference & Method & Muscle Strength \\
\hline $\begin{array}{l}\text { Holle et al } \\
(1984)^{15}\end{array}$ & $\begin{array}{l}2 \text { complete SCI } \\
\text { Quad. strengthening, sit to stand and gait } \\
\text { Follow up } 9 \text { mo. }\end{array}$ & $\begin{array}{l}\text { Quad. force: inc. between } 3-4 x \\
\text { Baseline between } 10-50 \mathrm{~N} \\
9 \text { mo. between } 40-180 \mathrm{~N}\end{array}$ \\
\hline $\begin{array}{l}\text { Hjeltnes et al } \\
(1990)^{3}\end{array}$ & $\begin{array}{l}1 \text { complete } \mathrm{T} 12 \mathrm{SCI} \\
8 \text { wk strengthening then gait training } \\
\text { Follow up } 6 \text { mo. }\end{array}$ & $\begin{array}{l}\text { Knee torque: } 30 \mathrm{Nm} \text { at } 10 \mathrm{wk} \\
\text { Muscular endurance: } 5 \times \text { initial values } \\
\text { Thigh girth: inc. from } 41.5-45 \mathrm{~cm}\end{array}$ \\
\hline $\begin{array}{l}\text { Gallien et al } \\
(1995)^{2} \\
\text { Overlap of } \\
\text { patients with } \\
\text { Brissot }\end{array}$ & $\begin{array}{l}13 \text { complete } \mathrm{SCI} \\
\text { Parastep program: } 32 \text { sessions } \\
\text { Follow up: } 100 \pm 103 \text { days }\end{array}$ & $\begin{array}{l}\text { Quad. force: average inc. } 4-7 \mathrm{~kg} \\
\text { Thigh girth: average inc. } 5 \mathrm{~cm}\end{array}$ \\
\hline $\begin{array}{l}\text { Klose et al } \\
(1997)^{16}\end{array}$ & $\begin{array}{l}16 \text { complete SCI } \\
\text { Parastep program: } 32 \text { sessions } \\
\text { Measured pre- and post-gait training }\end{array}$ & $\begin{array}{l}\text { Limb girth }(\mathrm{cm}) \text { : sig. inc. thigh } 42.2-44.6 \text {, calf } \\
31.4-32.8 \text {. Lean tissue mass: sig. inc. } 1.2 \mathrm{~kg} \\
\text { Skinfold measures: sig. dec. } 15.7-14.4 \mathrm{~cm}\end{array}$ \\
\hline $\begin{array}{l}\text { Spadone et al } \\
(2003)^{10}\end{array}$ & $\begin{array}{l}\text { Single case study of T } 4 / 5 \text { complete SCI } \\
50 \text { sessions Hybrid Orthotic and } 50 \text { of Parastep } \\
\text { Measured at the completion of all gait training }\end{array}$ & $\begin{array}{l}\text { Isometric quad.: inc. from } 40-80 \mathrm{Nm} \text { with walking } \\
\text { using both systems }\end{array}$ \\
\hline $\begin{array}{l}\text { Johnston et al } \\
(2005)^{17}\end{array}$ & $\begin{array}{l}3 \text { complete SCI } \\
4 \text { wk strengthening, } 13 \text { wk gait } \\
\text { Measured baseline, } 4 \text { and } 21 \mathrm{wk}\end{array}$ & $\begin{array}{l}\text { Isometric quad.: strength inc. from range } 15-34 \text { to } \\
30-67 \mathrm{Nm} \text { during strengthening phase }\end{array}$ \\
\hline $\begin{array}{l}\text { Brissot et al } \\
(2000)^{18}\end{array}$ & $\begin{array}{l}13 \text { complete, } 2 \text { incomplete SCI } \\
\text { Parastep program: } 32 \text { sessions progressing from } \\
\text { strength, standing and gait }\end{array}$ & $\begin{array}{l}\text { Quad. force: inc. } 4-7 \mathrm{~kg} \\
\text { Thigh girth: average inc. } 5 \mathrm{~cm}\end{array}$ \\
\hline $\begin{array}{l}\text { Granat et al } \\
(1992)^{11}\end{array}$ & 6 incomplete SCI & Quad. moment: sig. inc. \\
\hline $\begin{array}{l}\text { Granat et al } \\
(1993)^{12}\end{array}$ & $\begin{array}{l}6 \text { mo. strengthening, } 3 \text { mo. gait training } \\
\text { Measured pre- and post-gait training }\end{array}$ & $\begin{array}{l}\text { Baseline range } 4-152 \mathrm{Nm} \\
\text { End of gait training range } 7-159 \mathrm{Nm}\end{array}$ \\
\hline
\end{tabular}

Abbreviations: dec., decrease; inc., increase; mo., month(s); quad., quadriceps muscle; SCI, spinal cord injury; sig., significant (a $P$-level of 0.05 or less achieved); wk, week(s)

Table 4 Summary of investigations into fitness

\begin{tabular}{|c|c|c|}
\hline Reference & Method & Cardiorespiratory variables \\
\hline $\begin{array}{l}\text { Jacobs et al } \\
(1997)^{19}\end{array}$ & $\begin{array}{l}15 \text { complete SCI } \\
\text { Parastep gait program ( } 32 \text { sessions) } \\
\text { Measured pre- and post-training ( } 0 \text { and } 11 \mathrm{wk})\end{array}$ & $\begin{array}{l}\text { Arm crank: sig. changes peak work (mean } 48-60 \mathrm{~W}) \text {, } \\
\mathrm{VO}_{2 \text { peak }}(\mathrm{mean} 20-23 \mathrm{ml} / \mathrm{kg} / \mathrm{min}) \text {, fatigue time } \\
\text { (mean } 15-19 \mathrm{~min}), \mathrm{HR}_{\text {peak }}(189-183 \text { beats } / \mathrm{min})\end{array}$ \\
\hline $\begin{array}{l}\text { Brissot et al } \\
(2000)^{18}\end{array}$ & $\begin{array}{l}13 \text { complete, } 2 \text { incomplete SCI } \\
\text { Parastep program: } 32 \text { sessions progressing from strength, } \\
\text { standing and gait } \\
\text { Follow up } 40 \pm 11 \mathrm{mo} .\end{array}$ & $\begin{array}{l}(n=1) 6 \text { mo. follow up after continued use of } \\
\text { Parastep no sig. change in max. HR, peak } \mathrm{VO}_{2}\end{array}$ \\
\hline
\end{tabular}

Abbreviations: mo., month(s); SCI, spinal cord injury; sig., significant (a P-level of 0.05 or less achieved); wk, week(s)

Functional outcomes Gait parameters: Gait performance has been evaluated in some trials using a range of measures, such as walking distance, velocity, cadence, step length and lower limb kinematics. Since their common purpose was to evaluate walking performance after FES gait training, these studies proposed that there would be significant improvements in gait parameters or the functional ability to walk over the course of training. In addition, authors expected to find significant differences in ambulatory outcomes between persons with complete versus incomplete SCI. FES gait studies have predominantly focused on people with incomplete 
Table 5 Summary of investigations into gait

\begin{tabular}{|c|c|c|}
\hline Reference & Method & Gait variables \\
\hline $\begin{array}{l}\text { Braun et al }(1985)^{20} \\
\text { Isakov et al }(1986)^{21} \\
\text { Mizrahi et al }(1985)^{22}\end{array}$ & $\begin{array}{l}4 \text { complete SCI } \\
\text { Individualized programs of muscle } \\
\text { strengthening, weight bearing and gait } \\
6 \text { mo. follow up }\end{array}$ & $\begin{array}{l}\text { Progressive inc. in gait velocity (approx. } \\
3.15 \mathrm{~cm} / \mathrm{s} \text { ) and stride length (approx. } 6.9 \mathrm{~cm} \text { ) } \\
\text { Progressive dec. in contact (approx. } 1.5 \mathrm{~s} \text { ) and } \\
\text { stride time (approx. } 5.3 \mathrm{~s} \text { ) }\end{array}$ \\
\hline Klose et al $(1997)^{16}$ & $\begin{array}{l}16 \text { complete SCI } \\
\text { Parastep program: } 32 \text { sessions } \\
\text { Measured pre- and post-gait training }\end{array}$ & $\begin{array}{l}\text { Sig. inc. in distance (mean of less than } \\
10-120 \mathrm{~m}) \text {, time (mean } 5-22 \mathrm{~min}) \text { and velocity } \\
(\text { mean } 2.3-9 \mathrm{~cm} / \mathrm{s})\end{array}$ \\
\hline Granat et al $(1993)^{12}$ & $\begin{array}{l}6 \text { incomplete SCI } \\
6 \text { mo. strengthening, } 3 \text { mo. gait training } \\
\text { Measured pre- and post-gait training }\end{array}$ & $\begin{array}{l}\text { Group averaged no change in velocity or } \\
\text { cadence but inc. stride length (mean inc. } 5 \mathrm{~cm} \text { ) }\end{array}$ \\
\hline $\begin{array}{l}\text { Ladouceur et al } \\
(2000)^{23,24}\end{array}$ & $\begin{array}{l}14 \text { incomplete SCI } \\
\text { FES gait for up to } 12 \text { mo. } \\
\text { Measured before and throughout } 12 \mathrm{mo} .\end{array}$ & $\begin{array}{l}(n=10) \text { Sig. inc. in velocity }(\text { mean } 10 \mathrm{~cm} / \mathrm{s}) \text {, } \\
\text { minor inc. stride length (mean } 12 \mathrm{~cm}), \text { dec. } \\
\text { stance time (mean } 0.22 \mathrm{~s}) \text {. Joint kinematics no } \\
\text { sig. changes }\end{array}$ \\
\hline Field-Fote $(2001)^{25}$ & $\begin{array}{l}19 \text { incomplete SCI with asymmetrical leg } \\
\text { strength } \\
36 \text { sessions FES and BWS TM walking } \\
\text { Pre- and post-training measurements ( } 0 \text { and } \\
12 \text { wk) }\end{array}$ & $\begin{array}{l}\text { TM walking: inc. velocity (mean } 26 \mathrm{~cm} / \mathrm{s}) \text { and } \\
\text { distance } / \text { session }(\text { mean } 150 \mathrm{~m}) \\
\text { OG walking: inc. velocity }(\text { mean } 9 \mathrm{~cm} / \mathrm{s})\end{array}$ \\
\hline Field-Fote et al $(2002)^{26}$ & $\begin{array}{l}14 \text { incomplete SCI } \\
36 \text { session FES and BWS TM walking } \\
\text { Pre- and post-training measures ( } 0 \text { and } 12 \mathrm{wk})\end{array}$ & $\begin{array}{l}\text { TM walking: inc. velocity (range } 41-763 \% \text { ) } \\
\text { OG walking: inc. velocity (range } 16-220 \% \text { ) and } \\
\text { more consistent gait cycle }\end{array}$ \\
\hline Johnston et al $(2003)^{27}$ & $\begin{array}{l}3 \text { incomplete SCI children } \\
41 / 2-7 \text { wk daily training of strengthening } \\
\text { followed by gait training } \\
\text { Pre- and post-training, } 3,6 \text { and } 12 \mathrm{mo} \text {. } \\
\text { follow up }\end{array}$ & $\begin{array}{l}\text { Sig. inc. in walking distance }(67-294 \mathrm{~m}) \text {, velocity } \\
(32-52.6 \mathrm{~cm} / \mathrm{s}) \text { and step length }(46-53 \mathrm{~cm}) \\
\text { without FES from baseline to } 12 \mathrm{mo} \text {. } \\
\text { Improved pelvic stability and joint kinematics }\end{array}$ \\
\hline Hesse et al $(2004)^{28}$ & $\begin{array}{l}4 \text { incomplete SCI as case studies } \\
5 \text { wk electomechanical gait trainer with FES } \\
\text { Measured pre- and post-training }\end{array}$ & $\begin{array}{l}\text { Inc. velocity (baseline range } 0-32 \text { improved to } \\
15-81 \mathrm{~cm} / \mathrm{s} \text { ) }\end{array}$ \\
\hline Postans et al $(2004)^{29}$ & $\begin{array}{l}14 \text { incomplete SCI } \\
\text { Crossover trial: } 4 \text { wk physio versus PWB TM } \\
\text { training with FES } \\
\text { Assessed baseline and after each } 4 \mathrm{wk}(n=10)\end{array}$ & $\begin{array}{l}\text { Gait velocity inc. after both therapies (mean } \\
18 \text { and } 15 \mathrm{~cm} / \mathrm{s} \text { ). Greater inc. in endurance after } \\
\text { TM/FES therapy. Cadence no change }\end{array}$ \\
\hline Field-Fote et al $(2005)^{30}$ & $\begin{array}{l}27 \text { incomplete SCI } \\
12 \text { wk daily BWS training. } 4 \text { gps. using TM and } \\
\text { OG, with and without FES } \\
\text { Pre- and post-training measures }\end{array}$ & $\begin{array}{l}6 \mathrm{~m} \text { walk test: sig. inc. in speed for TM } \\
(12-17 \mathrm{~cm} / \mathrm{s}) \text { and OG }(14-19 \mathrm{~cm} / \mathrm{s}) \text { with FES }\end{array}$ \\
\hline $\begin{array}{l}\text { Thrasher et al }(2006)^{31} \\
\text { Thrasher et al }(2003)^{32}\end{array}$ & $\begin{array}{l}5 \text { incomplete SCI } \\
12-18 \text { wk FES gait training } 2-5 \text { times per wk } \\
\text { Pre- and post-training, } 10 \mathrm{wk} \text { follow up on } \\
3 \text { of } 5\end{array}$ & $\begin{array}{l}\text { Non-FES gait: } 4 / 5 \text { sig. inc. in walking velocity } \\
\text { over treatment with slight dec. at follow up. } \\
\text { Velocity inc. due to sig. inc. in stride length } \\
\text { and step frequency }\end{array}$ \\
\hline
\end{tabular}

Abbreviations: BWS, body weight support; dec., decrease; FES, functional electrical stimulation; gps., groups; inc., increase; mo., month(s); OG, overground; PWB, partial weight bearing; s, seconds; SCI, spinal cord injury; sig., significant (a $P$-level of 0.05 or less achieved); TM, treadmill; wk, week(s)

SCI (9 of 11 studies) in whom the greatest functional improvements were anticipated.

Eleven trials are presented in Table 5 examining various parameters of gait. Most investigations demon- strated improvements in gait parameters following a period of FES gait training, with the cohort of incomplete participants demonstrating carry over into their overground walking ability without FES. Studies 
Table 6 Summary of investigations into the energy cost of walking

\begin{tabular}{lll}
\hline Reference & Method & Energy cost of walking \\
\hline Brissot et al (2000) $)^{18}$ & 13 complete, 2 incomplete SCI & $(n=1) 6$ mo. follow up after continued use of \\
& $\begin{array}{l}\text { Parastep program: 32 sessions progressing } \\
\text { from strength, standing and gait }\end{array}$ & $\begin{array}{l}\text { Parastep no sig. change in energy cost of walking } \\
(\mathrm{J} / \mathrm{kg} / \mathrm{m})\end{array}$ \\
& Follow up 40 \pm 11 mo.
\end{tabular}

Granat et al (1993) ${ }^{12} \quad 6$ incomplete SCI

6 mo. strengthening, 3 mo. gait training

Measured pre- and post-gait training

Ladouceur et al $(2000)^{24}$

Johnston et al $(2003)^{27}$

Thrasher et al $(2003)^{32}$
14 incomplete SCI

FES gait for 6-12 mo.

Measured pre- and post-gait training

3 incomplete SCI children

$41 / 2$ to 7 wk daily training of strengthening

followed by gait training

Pre- and post-training 3, 6 and $12 \mathrm{mo}$.

follow up

3 incomplete SCI

$12-18$ wk FES gait training $2-5 \times$ per wk

Pre- and post-training
PCI dec. on average 0.09 over group. 3 of 6 had sig. dec

( $n=9$ over $3 \mathrm{mo}$ ) $8 / 9$ positive results. $3 / 9$ PCI constant, vel inc.; 3/9 PCI dec., vel constant; 1/9 PCI dec., vel inc.; 1/9 PCI and vel inc.; PCI inc., vel constant

Sig. dec. in $\mathrm{VO}_{2}$ and energy cost of walking (baseline energy cost 0.79 dec. to $0.441 / \mathrm{kg} / \mathrm{m}$ over 12 mo. $)^{\mathrm{a}}$

No significant change in PCI

Abbreviations: dec., decrease(s); FES, functional electrical stimulation; inc., increase; mo., month(s); PCI, physiological cost index; SCI, spinal cord injury; sig., significant (a $P$-level of 0.05 or less achieved); vel, velocity; wk, week(s)

${ }^{\mathrm{a}}$ These values were reported as $\mathrm{VO}_{2} / \mathrm{kg} / \mathrm{m}$ we assume they are $1 / \mathrm{kg} / \mathrm{m}$

consistently reported an increase in walking distance and time, as well as an improvement in stride length and velocity. Unfortunately, statistical significance may not have been always demonstrated due to small sample sizes, low statistical power and large within-group variability of measures at baseline and follow up.

Three studies evaluated joint kinematics, in a population of incomplete SCI. Johnston et $a l^{27}$ reported improved pelvic stability (pelvic rotation and tilt), and knee and hip flexion/extension approaching a more 'normal' pattern. In contrast, Ladouceur et $a l^{23,24}$ and Field-Fote $e a^{26}$ observed no significant changes in hip, knee and ankle flexion/extension, despite the gait cycle becoming more consistent.

Energy cost of gait: Mixed results have been reported in variables that have attempted to benchmark the energy cost of FES gait (Table 6). Various measures have been derived to quantify energy cost during ambulation, including physiological cost index (PCI; beats $/ \mathrm{min})$, net oxygen cost $(1 / \mathrm{kg} / \mathrm{m})$ and energy expenditure $(\mathrm{J} / \mathrm{kg} / \mathrm{m})$. In the three studies using PCI as a measure, the most consistent reduction in PCI were reported by Ladouceur et $a l,{ }^{24}$ who did not find significant increases in walking velocity over the course of training. In contrast, Brissot et $a l^{18}$ found no significant changes in energy expenditure, measured in $\mathrm{J} / \mathrm{kg} / \mathrm{m}$. Johnston et $\mathrm{al}^{27}$ observed a significant reduction in the net energy cost of walking $\left(\mathrm{VO}_{2} / \mathrm{kg} / \mathrm{m}\right)$, but again lack of standardization in walking speed between tests may have accounted for these variations.
Activities of daily living: Functional performance is strongly influenced by the level of lesion (paraplegia versus tetraplegia) and degree of neurological impairment (complete versus incomplete), with a greater range of variables available to measure improved functionality with FES in patients with incomplete SCI (Table 7). In patients with complete SCI, assessment is generally limited to standing time and temporospatial gait parameters with a requirement for walking aids assumed, whereas in persons with incomplete SCI, a greater range of functional activities has been assessed. Gait performance has been examined in terms of the number of assistive devices/therapist(s) required and number of deviations on an observational gait scale. Function has been measured using the Barthel index ${ }^{12}$ and a Mobility score. ${ }^{23}$ An improvement in weight bearing/standing time is the other factor that has been commented on. The only duplication in outcome measures between studies has been the need for therapist or assistive devices during gait. On this outcome, improvements have consistently been found with FES gait training.

Comparison of FES versus orthoses The studies presented in Table 8 compared gait parameters, energy expenditure and activities of daily living using FES versus orthotic systems. This table also includes investigations that compared gait and energy expenditure with and without FES. Once again varying populations, 
Table 7 Summary of investigations into function using FES

\begin{tabular}{|c|c|c|}
\hline Reference & Method & Function \\
\hline $\begin{array}{l}\text { Braun et al }(1985)^{20} \\
\text { Isakov et al }(1986)^{21} \\
\text { Mizrahi et al }(1985)^{22}\end{array}$ & $\begin{array}{l}4 \text { complete SCI } \\
\text { Individual programs of muscle strengthening, } \\
\text { weight bearing and gait } 6 \text { mo. follow up }\end{array}$ & $\begin{array}{l}\text { Inc. time in standing (baseline range } 0.25-4 \text { to } \\
2.2-20 \text { min at } 6 \text { mo.) }\end{array}$ \\
\hline Brissot et al $(2000)^{18}$ & $\begin{array}{l}13 \text { complete, } 2 \text { incomplete SCI } \\
\text { Parastep program: } 32 \text { sessions progressing } \\
\text { from strength, standing and gait } \\
\text { Follow up } 40 \pm 11 \text { mo. }\end{array}$ & $\begin{array}{l}13 / 15 \text { independent gait with FES, } 1 / 2 \\
\text { incomplete patient walk without FES } \\
5 / 15 \text { continued home use for fitness not } \\
\text { functional ambulation }\end{array}$ \\
\hline Granat et al (1993) ${ }^{12}$ & $\begin{array}{l}6 \text { incomplete SCI } \\
6 \text { mo. strengthening, } 3 \text { mo. gait training } \\
\text { Measured pre- and post-gait training }\end{array}$ & Barthel index: no change \\
\hline $\begin{array}{l}\text { Ladouceur et al } \\
(2000)^{23} \\
\text { Ladouceur et al } \\
(1997)^{33}\end{array}$ & $\begin{array}{l}14 \text { incomplete SCI } \\
\text { FES gait for up to } 12 \text { mo. } \\
\text { Measured before and throughout } 12 \mathrm{mo} \text {. }\end{array}$ & $\begin{array}{l}\text { Mobility scale ( } 84 \text { point max.) sig. inc. (mean } \\
\text { inc. } 6.4 \text { points), } 7 / 14 \text { dec. assistive devices }\end{array}$ \\
\hline Field-Fote $(2001)^{25}$ & $\begin{array}{l}19 \text { incomplete SCI with asymmetrical leg } \\
\text { strength } \\
36 \text { sessions FES and BWS treadmill walking } \\
\text { Pre- and post-training measurements ( } 0 \text { and } \\
12 \mathrm{wk})\end{array}$ & $\begin{array}{l}\text { Therapist assistance required by } 6 \text { patients } \\
\text { pre-training and only } 2 \text { post -training }\end{array}$ \\
\hline Hesse et al $(2004)^{28}$ & $\begin{array}{l}4 \text { incomplete SCI as case studies } \\
5 \text { wk electromechanical gait trainer with FES } \\
\text { Measured pre- and post-training }\end{array}$ & $\begin{array}{l}4 / 4 \text { dec. therapist support to walk } \\
3 / 4 \text { inc. weight bearing through legs }\end{array}$ \\
\hline Postans et al $(2004)^{29}$ & $\begin{array}{l}14 \text { incomplete SCI } \\
\text { Crossover trial: } 4 \text { wk physio versus } \mathrm{PWB} \\
\text { treadmill training with FES } \\
\text { Assessed baseline and after each } 4 \mathrm{wk}(n=10)\end{array}$ & $\begin{array}{l}\text { Dec. gait deviations on observational gait } \\
\text { scale after both interventions for those } \\
\text { achieving overground ambulation }\end{array}$ \\
\hline
\end{tabular}

Abbreviations: BWS, body weight support; dec., decrease; FES, functional electrical stimulation; inc., increase; mo., month(s); PWB, partial weight bearing; SCI, spinal cord injury; sig., significant (a $P$-level of 0.05 or less achieved); wk, week(s)

dissimilar methodologies and a large range of outcomes used to evaluate the systems make comparisons difficult and pooling of results impossible.

Overall, comparison of FES and orthotic systems on functional activities reveal differences that are activity dependent. Faster completion times were found on those activities that the system is suited better. For example FES is easier to don and move from the floor to standing. However, gait velocity and energy expenditure were not significantly different between FES and orthotic systems.

Despite the above variables not indicating significant differences between the systems, the preference reported in the literature is for the FES system. This preference by a majority of patients for FES has been reported as being related to cosmetic reasons with perhaps the FES system being slightly easier to don; therefore, allowing the participant greater independence.

\section{Discussion}

This review has highlighted that research in this area has most commonly focused on measuring primary out- comes of gait performance and function, with relatively little attention paid to possible secondary health or therapeutic benefits of FES gait. Most aspects require further research. The available evidence supports the use of FES gait training for the primary benefits of improving walking ability (eg walking faster, further and for longer) and for achieving key functional outcomes (ie requiring less assistance and being more independent in community), for persons with incomplete SCI lesions.

In summary of the published investigations to date there is no evidence to support changes in bone mineral density or joint kinematics and conflicting evidence for a reduced energy cost of gait. Preliminary research suggests there may be benefits for joint health, in psychological outlook and in cardiorespiratory fitness. Spasticity may be reduced for participants with incomplete SCI but there is no evidence to support this for participants with complete SCI. Muscle strength has been proven to increase for participants with complete SCI, but there is only preliminary data supporting this for participants with incomplete lesions. Gait parameters have been demonstrated to improve in distance, 
Table 8 Comparison of FES to alternative systems

\begin{tabular}{|c|c|c|c|c|c|}
\hline \multirow{2}{*}{ Reference } & \multirow{2}{*}{ Method } & \multirow{2}{*}{ Task } & \multicolumn{3}{|c|}{ Comparison } \\
\hline & & & Outcome & FES & Orthotic/without FES \\
\hline Marsolais et al $(1988)^{34}$ & $\begin{array}{l}2 \text { complete SCI } \\
\text { FES strengthening, standing and gait } \\
\text { training plus resistance ex for inc. trunk } \\
\text { stability and arm crank ergometry for CV } \\
\text { fitness }\end{array}$ & $\begin{array}{l}\text { Energy expenditure of FES gait } \\
\text { compared to LLB }\end{array}$ & \multicolumn{3}{|c|}{$\begin{array}{l}\text { Comments: comparable energy costs at speeds of } 0.4-0.56 \mathrm{~m} / \mathrm{s} \\
\text { Orthotic gait: higher energy cost-relative to working muscle mass }\end{array}$} \\
\hline Hjeltnes et al $(1990)^{3}$ & $\begin{array}{l}1 \text { complete T12 SCI } \\
8 \text { wk strengthening then gait training } \\
\text { Follow up } 6 \text { mo. }\end{array}$ & $\begin{array}{l}\text { Gait comparison of FES versus } \\
\text { KAFO ( } 2 \text { trials })\end{array}$ & $\begin{array}{l}\text { Velocity } \\
\mathrm{VO}_{2} \\
\mathrm{~V}_{\mathrm{E}}\end{array}$ & $\begin{array}{l}\text { Av. } 1.05 \mathrm{~cm} / \mathrm{s} \\
17.5 \mathrm{ml} / \mathrm{kg} / \mathrm{min} \\
301 / \mathrm{min}\end{array}$ & $\begin{array}{l}\text { Av. } 0.86 \mathrm{~cm} / \mathrm{s} \\
13.5 \mathrm{ml} / \mathrm{kg} / \mathrm{min} \\
22.51 / \mathrm{min}\end{array}$ \\
\hline Goldfarb et al $(2003)^{35}$ & $\begin{array}{l}4 \text { case studies: } 3 \text { complete, } 1 \text { incomplete } \\
\text { SCI } \\
4-6 \text { wk quad. strengthening and FES } \\
\text { cycling followed by gait training }\end{array}$ & $\begin{array}{l}\text { Gait comparison of FES ( } 3 \text { trials) } \\
\text { versus controlled brake orthosis }(5 \\
\text { trials) }\end{array}$ & $\begin{array}{l}\mathrm{O}_{2} \text { consumption } \\
\text { Heart rate/min } \\
\text { Velocity }\end{array}$ & \multicolumn{2}{|c|}{$\begin{array}{l}\text { No sig. differences } \\
3 \text { of } 4 \text { lower } \% \text { inc. with orthotic } \\
1 \text { of } 4 \text { sig. difference } 0.092 \text { versus } 0.107 \mathrm{~m} / \mathrm{s}\end{array}$} \\
\hline Spadone et al $(2003)^{10}$ & $\begin{array}{l}\text { Single case study of T4/5 complete SCI } \\
50 \text { sessions Hybrid Orthotic and } 50 \\
\text { parastep comparing both }\end{array}$ & $\begin{array}{l}\text { Max. and self-selected gait speeds } \\
\text { comparing FES, orthotic and } \\
\text { hybrid system }\end{array}$ & $\begin{array}{l}\text { Self selected Vel. } \\
\mathrm{VO}_{2} \\
\mathrm{~V}_{\mathrm{E}}\end{array}$ & $\begin{array}{l}0.2 \mathrm{~km} / \mathrm{h} \\
1.33 \mathrm{l} / \mathrm{min} \\
30 \mathrm{l} / \mathrm{min}\end{array}$ & $\begin{array}{l}0.52 \mathrm{~km} / \mathrm{h} \\
1.151 / \mathrm{min} \\
20.91 / \mathrm{min}\end{array}$ \\
\hline Granat et al $(1992)^{11}$ & $\begin{array}{l}6 \text { incomplete SCI } \\
9-12 \text { mo. Individual strengthening, } \\
\text { standing and gait program } \\
\text { Follow up after } 2 \text { mo. of home use }\end{array}$ & $\begin{array}{l}\text { Gait performed with a rollator } \\
\text { using FES or orthoses, videotaped } \\
\text { in the gait laboratory over } 5 \text { trials }\end{array}$ & $\begin{array}{l}\text { Cadence } \\
\text { Velocity } \\
\text { Comments: ortho }\end{array}$ & \multicolumn{2}{|c|}{$\begin{array}{l}\text { FES sig. dec. compared to orthoses } \\
\text { No sig. differences }\end{array}$} \\
\hline Stein et al $(1993)^{36}$ & $\begin{array}{l}10 \text { incomplete SCI } \\
\text { Compared gait with and without FES } \\
\text { Gait analysis after varying amounts of } \\
\text { training }\end{array}$ & $\begin{array}{l}\text { Gait analysis with and without } \\
\text { FES over } 5 \mathrm{~m} \text { track ( } 3-6 \text { trials) } \\
\text { Energy expenditure ( } 1 \text { trial on } \\
\text { separate day) }\end{array}$ & $\begin{array}{l}\text { Velocity } \\
\text { Swing time } \\
\mathrm{O}_{2} \text { consumption }\end{array}$ & $\begin{array}{l}\text { FES faster me } \\
\text { FES decreased } \\
\text { No sig. differe }\end{array}$ & $\begin{array}{l}\text { ence } 6.67 \mathrm{~cm} / \mathrm{s} \\
\% \text { of gait cycle }(n=5)\end{array}$ \\
\hline Wieler et al $(1999)^{37}$ & $\begin{array}{l}31 \text { incomplete SCI } \\
\text { Compared gait with and without FES } \\
\text { Varying training times }\end{array}$ & $\begin{array}{l}\text { Video analysis of gait with and } \\
\text { without FES over } 5 \mathrm{~m} \text { track } \\
\text { (4 trials) }\end{array}$ & \multicolumn{3}{|c|}{$\begin{array}{l}\text { Comments: velocity inc. with and without FES av inc. }=14 \mathrm{~cm} / \mathrm{s} \\
\text { Found a } 20 \% \text { training effect } \\
\text { Stride length sig. inc. over } 20 \% \text { with and without FES }\end{array}$} \\
\hline Ladouceur et al $(2000)^{24}$ & $\begin{array}{l}14 \text { incomplete SCI } \\
\text { FES gait for } 6-12 \text { mo. } \\
\text { Measured pre- and post-gait training }\end{array}$ & Gait analysis with and without FES & \multicolumn{3}{|c|}{$\begin{array}{l}\text { Comments: FES: }(n=10) \text { slight inc. in hip angle excursion, ankle } \\
\text { angle at foot contact and dorsiflexion during swing }\end{array}$} \\
\hline Johnston et al $(2003)^{27}$ & $\begin{array}{l}3 \text { incomplete SCI children } \\
41 / 2 \text { to } 7 \mathrm{wk} \text { daily training of } \\
\text { strengthening followed by gait training } \\
\text { Post training, } 3,6 \text { and } 12 \text { mo. follow up }\end{array}$ & $\begin{array}{l}\text { Gait analysis with and without FES } \\
12 \text { mo. follow up data presented for } \\
\text { comparison }\end{array}$ & $\begin{array}{l}\mathrm{VO}_{2} \\
\text { Velocity } \\
\text { Step Length } \\
\text { Cadence } \\
\text { Walk Distance }\end{array}$ & $\begin{array}{l}0.521 / \mathrm{kg} / \mathrm{m}^{\mathrm{a}} \\
47.2 \mathrm{~cm} / \mathrm{s} \\
45.3 \mathrm{~cm} \\
53.9 \mathrm{steps} / \mathrm{min} \\
265.1 \mathrm{~m}\end{array}$ & $\begin{array}{l}0.441 / \mathrm{kg} / \mathrm{m}^{\mathrm{a}} \\
52.6 \mathrm{~cm} / \mathrm{s} \\
53.0 \mathrm{~cm} \\
60.8 \mathrm{steps} / \mathrm{min} \\
294.8 \mathrm{~m}\end{array}$ \\
\hline Bonaroti et al (1999) 38 & $\begin{array}{l}5 \text { complete SCI children } \\
\text { Comparison of implanted FES to long leg } \\
\text { braces }\end{array}$ & $\begin{array}{l}7 \text { upright mobility tasks plus } \\
\text { donning equip. using FIM } \\
\text { scoring and completion times }\end{array}$ & $\begin{array}{l}\text { Donning } \\
\text { Stand and reach } \\
\text { High Transfer }\end{array}$ & $\begin{array}{l}523 \mathrm{~s} \\
40.8 \mathrm{~s} \\
70.4 \mathrm{~s}\end{array}$ & $\begin{array}{l}673.7 \mathrm{~s} \\
82.1 \mathrm{~s} \\
105.9 \mathrm{~s}\end{array}$ \\
\hline
\end{tabular}


Table 8 Continued

\begin{tabular}{|c|c|c|c|c|c|}
\hline \multirow{2}{*}{ Reference } & \multirow{2}{*}{ Method } & \multirow{2}{*}{ Task } & \multicolumn{3}{|c|}{ Comparison } \\
\hline & & & Outcome & FES & Orthotic/without FES \\
\hline & 4 wk training in both systems & comparing FES and LLB & $\begin{array}{l}\text { Toilet Transfer } \\
\text { Floor to Stand } \\
6 \mathrm{~m} \text { walk } \\
\text { Ascend stair } \\
\text { Descend stair } \\
\text { Comment: equal } \\
\text { FES preferred } 62\end{array}$ & $\begin{array}{l}85.9 \mathrm{~s} \\
61.3 \mathrm{~s} \\
50.9 \\
28.8 \mathrm{~s} \\
27.3 \mathrm{~s} \\
\text { more independen } \\
\text { of time by subjec }\end{array}$ & $\begin{array}{l}83.1 \mathrm{~s} \\
70.1 \mathrm{~s} \\
71.1 \\
32.0 \mathrm{~s} \\
27.3 \mathrm{~s} \\
\text { FES }(94 \%)\end{array}$ \\
\hline Bonaroti et al (1999) & $\begin{array}{l}\text { Single case study of } 11 \text { yo T10 complete } \\
\text { SCI } \\
\text { Strengthening, sit to stand, } 6 \mathrm{wk} \text { gait } \\
\text { training } \\
\text { Tested pre- and post- } 6 \mathrm{wk} \text { of training }\end{array}$ & $\begin{array}{l}\text { FES versus KAFO on mobility } \\
\text { tasks plus donning, standing } \\
\text { balance, functional standing tasks, } \\
\text { gait energy expenditure }\end{array}$ & $\begin{array}{l}\text { Donning } \\
\text { High Transfer } \\
\text { Bath Transfer } \\
\text { Floor to Stand } \\
\text { Ascend stair } \\
\text { Descend stair } \\
\text { Oxygen cost } \\
\text { Oxygen rate } \\
\text { Walk Distance } \\
\text { Velocity over } \\
\text { 100ft } \\
\text { Velocity over } \\
\text { max. }\end{array}$ & $\begin{array}{l}5 \mathrm{~min} \\
32.7 \mathrm{~s} \\
15.4 \mathrm{~s} \\
29.6 \mathrm{~s} \\
15.8 \mathrm{~s} \\
13.5 \mathrm{~s} \\
0.82 \mathrm{ml} / \mathrm{kg} / \mathrm{m} \\
20.06 \mathrm{ml} / \mathrm{kg} / \mathrm{min} \\
375 \mathrm{~m} \\
44.8 \mathrm{~m} / \mathrm{min} \\
\\
29.0 \mathrm{~m} / \mathrm{min}\end{array}$ & $\begin{array}{l}5 \mathrm{~min} 20 \mathrm{~s} \\
35.7 \mathrm{~s} \\
9.6 \mathrm{~s} \\
31.6 \mathrm{~s} \\
17.1 \mathrm{~s} \\
11.1 \mathrm{~s} \\
0.781 / \mathrm{kg} / \mathrm{m} \\
16.65 \mathrm{ml} / \mathrm{kg} / \mathrm{min} \\
371 \mathrm{~m} \\
37.6 \mathrm{~m} / \mathrm{min} \\
22.2 \mathrm{~m} / \mathrm{min}\end{array}$ \\
\hline Betz et al $(2002)^{40}$ & $\begin{array}{l}\text { Single case study of } 13 \text { yo T } 8 \text { complete SCI } \\
4 \text { wk strengthening, } 6 \text { wk gait, home use } \\
\text { Follow up } 6,12,24 \text { and } 36 \text { mo. } \\
\text { Comparison given after training only for } \\
\text { ease of comparison to other studies }\end{array}$ & $\begin{array}{l}7 \text { upright mobility tasks plus } \\
\text { donning equip. using FIM scoring } \\
\text { and completion times comparing } \\
\text { FES and LLB }\end{array}$ & $\begin{array}{l}\text { Donning } \\
\text { Stand and reach } \\
\text { High Transfer } \\
\text { Toilet Transfer } \\
\text { Floor to Stand } \\
6 \mathrm{~m} \text { walk } \\
\text { Ascend stair } \\
\text { Descend stair }\end{array}$ & $\begin{array}{l}106.6 \mathrm{~s} \\
48.62 \mathrm{~s} \\
27.21 \mathrm{~s} \\
11.26 \mathrm{~s} \\
24.25 \mathrm{~s} \\
7.86 \mathrm{~s} \\
11.84 \mathrm{~s} \\
14.6 \mathrm{~s}\end{array}$ & $\begin{array}{l}273 \mathrm{~s} \\
79.18 \mathrm{~s} \\
50.04 \mathrm{~s} \\
17.49 \mathrm{~s} \\
23.40 \mathrm{~s} \\
9.08 \mathrm{~s} \\
12.61 \mathrm{~s} \\
16.44 \mathrm{~s}\end{array}$ \\
\hline Johnston $(2003)^{41}$ & $\begin{array}{l}9 \text { complete SCI children } \\
2-4 \text { wk strengthening, standing, } 3-8 \text { wks } \\
\text { gait } \\
\text { Follow up when consistent performance } \\
\text { on tasks }\end{array}$ & $\begin{array}{l}7 \text { upright mobility tasks plus } \\
\text { donning equip. using FIM scoring } \\
\text { and completion times comparing } \\
\text { FES to LLB }\end{array}$ & $\begin{array}{l}\text { Donning } \\
\text { Stand and reach } \\
\text { High Transfer } \\
\text { Toilet Transfer } \\
\text { Floor to Stand } \\
6 \mathrm{~m} \text { walk } \\
\text { Ascend stair } \\
\text { Descend stair } \\
\text { Comment: equal } \\
\text { FES preferred } 87\end{array}$ & $\begin{array}{l}246.1 \mathrm{~s} \\
59.5 \mathrm{~s} \\
43.9 \mathrm{~s} \\
24.1 \mathrm{~s} \\
35.9 \mathrm{~s} \\
37.0 \mathrm{~s} \\
17.8 \mathrm{~s} \\
19.3 \mathrm{~s} \\
\text { more independen } \\
\text { \% of time by subj }\end{array}$ & $\begin{array}{l}466.7 \mathrm{~s} \\
109.4 \mathrm{~s} \\
68.5 \mathrm{~s} \\
24.1 \mathrm{~s} \\
35.9 \mathrm{~s} \\
37.0 \mathrm{~s} \\
17.8 \mathrm{~s} \\
19.3 \mathrm{~s} \\
\text { FES }\end{array}$ \\
\hline
\end{tabular}

Abbreviations: av, average; dec., decrease; FES, functional electrical stimulation; inc., increase; mo., month(s); SCI, spinal cord injury; s, seconds; sig., significant (a $P$-level of 0.05 or less achieved); vel, velocity; wk, week(s)

${ }^{\mathrm{a}}$ These values were reported as $\mathrm{VO}_{2} / \mathrm{kg} / \mathrm{m}$ we assume they are $1 \mathrm{~kg} / \mathrm{m}$ 
time, velocity and stride length with the evidence much stronger for participants with incomplete SCI.

However, while evaluating some of the clinical benefits or the functional efficacy of FES gait, the quality of these studies are low with no RCTs having been conducted, and single case studies a common research design. The completion of RCTs in this area will allow more definite conclusions to be drawn. RCTs will control for trends in time and ensure balanced groups for comparison, thereby ensuring the outcomes measured are more likely to be due to the intervention and not open to bias.

A broad range of benefits from FES gait training have been proposed, although only a few aspects have been evaluated objectively by multiple investigations, and often there are disparate methodological differences that make objective comparisons difficult. For example, using PCI as a measure of the energy cost of walking. PCI (calculated by the formula (walking HR-resting HR)/walking speed) is considered by some authors not to be an appropriate measure, since walking velocity has been demonstrated to change significantly during gait training in most studies. PCI more likely represents a measure of stress imposed upon the heart, and this is not always concordant with the 'true' energy cost of ambulation, because other factors such as upper body isometric muscle contractions engendered by ambulating with a walking aid ( $e g$ crutches, canes, etc.) alters the heart rate.

Some important aspects of FES gait training have still not been explored. For example, the potential benefit of FES gait for maintaining or improving muscle length has not been evaluated, although upright posture (eg tilt tables and standing frames) is commonly used in clinical practice. Therefore, drawing definitive conclusions about the benefits of FES walking for people with SCI is not possible in many domains of clinical, psychosocial or functional outcomes.

Additionally there are insufficient data to evaluate differences between implanted and surface FES electrodes. Of the 36 studies included in this review, only nine $(25 \%)$ used implanted systems with a further study using a mixed group consisting of both surface and implanted systems. Sample sizes in those papers using implanted electrodes were small and did not make up a large enough proportion of any outcome considered in this review to make objective evaluations.

Gait training via FES may increase muscle strength if initial deficits exist, but the gains may not be specific to weaker muscles, ${ }^{11,12,30}$ resulting in the majority of cited studies commencing with non-task-specific strength conditioning before progressing to gait training. The extremely low initial level of force/torque that may be generated, especially by individuals with complete SCI, usually necessitates such strength conditioning before gait training. Even after training, muscle strength can remain quite low, and the ability of participants to maintain their own body weight in single leg stance may be marginal, often requiring supplementary assistive devices that further limit functional capability.
In terms of the secondary clinical or health-related benefits of FES gait, there may be a reduction in muscle spasm for persons with incomplete SCI, but there is insufficient evidence to suggest this for those with complete lesions. Mechanical testing systems have detected changes in muscle spasm; however, whether these changes are sufficient to be clinically meaningful is debatable, since studies that have employed the Ashworth scale ${ }^{12,18,29}$ for assessing muscle spasm have not reported positive outcomes. Similarly, no changes have been reported for bone density, although it may be proposed that a greater dose and/or longer training period may be required to detect changes, since there has been recent positive findings after FES cycling. ${ }^{45}$ Only one study looked at joint changes with no deleterious effects observed. Similarly, only one study has examined psychological well-being, without demonstrating significant benefits. Overall, it is possible that selection bias may have influenced some of these results for clinical or health-related adaptations, with greater changes expected in those participants with the greater deficits (for example, more severe bone loss), who may not have met inclusion criteria. However, it is also likely that this field of research is plagued by the dual problems of low sample sizes and poor statistical power, as well as a lack of a clear dose: response relationship between the amount of FES gait training that might be required to achieve a secondary clinical or health-related outcome.

FES gait training improves walking speed and duration, thus imposing a greater cardiorespiratory and metabolic stress, as well as recruiting a greater volume of lower limb musculature, compared to orthotic gait systems. It therefore represents a useful cardiorespiratory fitness training modality as has been suggested by Jacobs et al ${ }^{19}$ The major changes after FES gait training are in walking parameters, although these aspects are not well researched in the complete SCI population. This population's results may also be influenced by improvements in the FES stimulation patterns rather than subject changes. Walking velocity has consistently demonstrated improvements after gait training, but like muscle strength, initial values are often low and the functionality or clinical significance of any changes is questionable. Velocity gains are commonly associated with an increased step length suggesting improvements in muscle strength and/or balance. Corresponding to these changes, observational assessments of gait have reported a decreased need for assistive devices or therapist assistance, supporting improvements in muscle strength as the patient can bear weight more effectively and has greater balance.

Volunteers in studies adhere to FES interventions well, but usage tends to drop off following the intervention (for example, Brissot et $a l^{18}$ ). Study participants, particularly with complete SCI lesions, have reported that FES gait is not functional and their use of the system is solely for the fitness benefits that accrue. ${ }^{18}$ The functional benefits of FES, apart from gait-related activities, have not been well investigated. Functional assessments used in the literature to date 
may lack sensitivity and specificity for this population. Changes achieved after FES gait training are often small and can be very task specific so the Barthel index, for example, may not reflect the true gains achieved through the training period. The volunteers commonly involved in FES trials are a select, highly motivated group. Their desire to participate in these highly demanding trials may be seen as their preconceived preference for alternative gait systems. Therefore their reported preference for FES over orthotic systems may be related to cosmetic and preconceived notions rather than functional gains of one system over the other.

\section{Conclusions}

FES gait offers benefits in walking ability for people with incomplete SCI injuries. There are muscle strength and endurance gains to be achieved through regular walking and their gait becomes closer to a more normal walking pattern (increased velocity, increased stance time, greater step length and decrease need for assistive devices) with training. As yet there is not sufficient evidence to make the same claims for people with complete lesions. Regarding the secondary outcomes of FES gait, many are still insufficiently researched to draw conclusions. Muscle spasm has been reduced for people with incomplete SCI and cardiorespiratory fitness is augmented, as a result of the high metabolic and cardiorespiratory stresses imposed by the FES gait, but further claims are difficult to support at this stage. Further good quality, randomized, controlled intervention studies are required to document the efficacy of FES gait training that may be related to clinical sequelae following SCI.

\section{References}

1 Agarwal $\mathrm{S}$ et al. Long-term user perceptions of an implanted neuroprosthesis for exercise, standing, and transfers after spinal cord injury. J Rehabil Res Dev 2003; 40: 241-252.

2 Gallien $\mathrm{P}$ et al. Restoration of gait by functional electrical stimulation for spinal cord injured patients. Paraplegia 1995; 33: 660-664.

3 Hjeltnes N, Lannem A. Functional neuromuscular stimulation in 4 patients with complete paraplegia. Paraplegia 1990; 28: 235-243.

4 Kobetic R et al. Implanted functional electrical stimulation system for mobility in paraplegia: a follow-up case report. IEEE Trans Rehabil Eng 1999; 7: 390-398.

5 Raymond J, Crameri R. Electrical stimulation for individuals with spinal cord injury. Am J Med Sports 2001; 3: 209-222.

6 Brown-Triolo DL, Roach MJ, Nelson K, Triolo RJ. Consumer perspectives on mobility: implications for neuroprosthesis design. $J$ Rehabil Res Dev 2002; 39: 659-669.

7 Anderson KD. Targeting recovery: priorities of the spinal cord-injured population. $J$ Neurotrauma 2004; 21: 1371-1383.
8 Jacobs PL, Nash MS. Modes, benefits, and risks of voluntary an electrically induced exercise in persons with spinal cord injury. J Spinal Cord Med 2001; 24: 10-18.

9 Ijzerman MJ, Baardman G, Hermens HJ, Veltink PH, Boom HBK, Zilvold G. Comparative trials on hybrid walking systems for people with paraplegia: an analysis of study methodology. Prosthet Orthot Int 1999; 23: 260-273.

10 Spadone R et al. Energy consumption of locomotion with orthosis versus Parastep-assisted gait: a single case study. Spinal Cord 2003; 41: 97-104.

11 Granat M, Keating JF, Smith AC, Delargy M, Andrews BJ. The use of functional electrical stimulation to assist gait in patients with incomplete spinal cord injury. Disabil Rehabil 1992; 14: 93-97.

12 Granat MH, Ferguson AC, Andrews BJ, Delargy M. The role of functional electrical stimulation in the rehabilitation of patients with incomplete spinal cord injury - observed benefits during gait studies. Paraplegia 1993; 31: 207-215.

13 Mirbagheri MM, Ladouceur M, Barbeau H, Kearney RE. The effects of long-term FES-assisted walking on intrinsic and reflex dynamic stiffness in spastic spinal-cord-injured subjects. IEEE Trans Neural Syst Rehabil Eng 2002; 10: 280-289.

14 Needham-Shropshire BM, Broton JG, Klose KJ, Lebwohl N, Guest RS, Jacobs PL. Evaluation of a training program for persons with SCI paraplegia using the Parastep 1 ambulation system: part 3. Lack of effect on bone mineral density. Arch Phys Med Rehabil 1997; 78: 799-803.

15 Holle J, Frey M, Gruber H, Kern H, Stohr H, Thoma H. Functional electrostimulation of paraplegics: experimental investigatyions and first clincial experience with an implantable stimulation device. Orthopedics 1984; 7: 1145-1155.

16 Klose $\mathrm{KJ}$ et al. Evaluation of a training program for persons with SCI paraplegia using the Parastep 1 ambulation system: part 1. Ambulation performance and anthropometric measures. Arch Phys Med Rehabil 1997; 78: 789-793.

17 Johnston TE et al. Implantable FES system for upright mobility and bladder and bowel function for individuals with spinal cord injury. Spinal Cord 2005; 43: 713-723.

18 Brissot $\mathrm{R}$ et al. Clinical experience with functional electrical stimulation-assisted gait with parastep in spinal cord-injured patients. Spine 2000; 25: 501-508.

19 Jacobs PL, Nash MS, Klose KJ, Guest RS, NeedhamShropshire BM, Green BA. Evaluation of a training program for persons with SCI paraplegia using the Parastep 1 ambulation system: part 2. Effects on physiological responses to peak arm ergometry. Arch Phys Med Rehabil 1997; 78: 794-798.

20 Braun Z, Mizrahi J, Najenson T, Graupe D. Activation of paraplegic patients by functional electrical stimulation: training and biomechanical evaluation. Scand J Rehabil Med Suppl 1985; 12: 93-101.

21 Isakov E, Mizrahi J, Najenson T. Biomechanical and physiological evaluation of FES-activated paraplegic patients. J Rehabil Res Dev 1986; 23: 9-19.

22 Mizrahi J, Braun Z, Najenson T, Graupe D. Quantitative weightbearing and gait evaluation of paraplegics using functional electrical stimulation. Med Biol Eng Comput 1985; 23: 101-107.

23 Ladouceur M, Barbeau H. Functional electrical stimulation-assisted walking for persons with incomplete spinal injuries: longitudinal changes in maximal overground walking speed. Scand J Rehabil Med 2000; 32: 28-36.

24 Ladouceur M, Barbeau H. Functional electrical stimulation-assisted walking for persons with incomplete spinal 
injuries: changes in the kinematics and physiological cost of overground walking. Scand J Rehabil Med 2000; 32: 72-79.

25 Field-Fote EC. Combined use of body weight support, functional electric stimulation, and treadmill training to improve walking ability in individuals with chronic incomplete spinal cord injury. Arch Phys Med Rehabil 2001; 82: 818-824.

26 Field-Fote EC, Tepavac D. Improved intralimb coordination in people with incomplete spinal cord injury following training with body weight support and electrical stimulation. Phys Ther 2002; 82: 707-715.

27 Johnston TE, Finson RL, Smith BT, Bonaroti DM, Betz RR, Mulcahey MJ. Functional electrical stimulation for augmented walking in adolescents with incomplete spinal cord injury. J Spinal Cord Med 2003; 26: 390-400.

28 Hesse S, Werner C, Bardeleben A. Electromechanical gait training with functional electrical stimulation: case studies in spinal cord injury. Spinal Cord 2004; 42: 346-352.

29 Postans NJ, Hasler JP, Granat MH, Maxwell DJ. Functional electric stimulation to augment partial weightbearing supported treadmill training for patients with acute incomplete spinal cord injury: a pilot study. Arch Phys Med Rehabil 2004; 85: 604-610.

30 Field-Fote EC, Lindley SD, Sherman AL. Locomotor training approaches for individuals with spinal cord injury: a preliminary report of walking-related outcomes. J Neurol Phys Ther 2005; 29: 127-137.

31 Thrasher TA, Flett HM, Popovic MR. Gait training regimen for incomplete spinal cord injury using functional electrical stimulation. Spinal Cord 2006; 44: 357-361.

32 Thrasher TA, Popovic MR. FES-assisted walking for rehabilitation of incomplete spinal cord injury. International Functional Electrical Stimulation Society Conference Novotel Twin Waters Resort Maroochydore, 1-5 July 2003, Sunshine Coast, Queensland, 2003 pp 131-134.

33 Ladouceur M, Barbeau H. Effects of walking training with a functional electrical stimulation assisted orthosis for spinal cord injured persons: a longitudinal study. In: Popovic VD (ed) IFESS 97 - Second Annual Conference: International Functional Electrical Stimulation Society and Neural Protheses 97 - Fifth Triennial Conference: Neural Prostheses: Motor Systems, 16-21 August, 1997, Simon Fraser University, Burnaby, British Columbia, Canada 1997 pp $160-163$.

34 Marsolais EB, Edwards BG. Energy costs of walking and standing with functional neuromuscular stimulation and long leg braces. Arch Phys Med Rehabil 1988; 69: 243-249.
35 Goldfarb M, Korkowski K, Harrold B, Durfee W. Preliminary evaluation of a controlled-brake orthosis for FES-aided gait. IEEE Trans Neural Syst Rehabil Eng 2003; 11: $241-248$.

36 Stein RB et al. Electrical systems for improving locomotion after incomplete spinal cord injury: an assessment. Arch Phys Med Rehabil 1993; 74: 954-959.

37 Wieler $\mathrm{M}$ et al. Multicenter evaluation of electrical stimulation systems for walking. Arch Phys Med Rehabil 1999; 80: 495-500.

38 Bonaroti D, Akers JM, Smith BT, Mulcahey MJ, Betz RR. Comparison of functional electrical stimulation to long leg braces for upright mobility for children with complete thoracic level spinal injuries. Arch Phys Med Rehabil 1999; 80: 1047-1053.

39 Bonaroti D, Akers J, Smith BT, Mulcahey MJ, Betz RR. A comparison of FES with KAFO for providing ambulation and upright mobility in a child with a complete thoracic spinal cord injury. J Spinal Cord Med 1999; 22: 159-166.

40 Betz RR, Johnston TE, Smith BT, Mulcahey MJ, McCarthy JJ. Three-year follow-up of an implanted functional electrical stimulation system for upright mobility in a child with a thoracic level spinal cord injury. J Spinal Cord Med 2002; 25: 345-350.

41 Johnston TE, Betz RR, Smith BT, Mulcahey MJ. Implanted functional electrical stimulation: an alternative for standing and walking in pediatric spinal cord injury. Spinal Cord 2003; 41: 144-152.

42 Betz R, Boden B, Triolo R, Mesgarzadeh M, Gardner E, Fife R. Effects of functional electrical stimulation on the joints of adolescents with spinal cord injury. Paraplegia 1996; 34: 127-136.

43 Rizzo M, Betz RR, Mulcahey MJ, Smith BT. Magnetic resonance imaging data in the evaluation of effects of functional electrical stimulation on knee joints of adolescents with spinal cord injury. J Spinal Cord Med 1998; 21: 124-130.

44 Guest RS, Klose KJ, Needham-Shropshire BM, Jacobs PL. Evaluation of a training program for persons with SCI paraplegia using the Parastep 1 ambulation system: part 4 . Effect on physical self-concept and depression. Arch Phys Med Rehabil 1997; 78: 804-807.

45 Eser P, de Bruin ED, Telley I, Lechner HE, Knecht H, Stussi E. Effect of electrical stimulation-induced cycling on bone mineral density in spinal cord-injured patients. Eur $J$ Clin Invest 2003; 33: 412-419. 